\title{
Widespread Disease
}

National Cancer Institute

\section{Source}

National Cancer Institute. Widespread Disease. NCI Thesaurus. Code C38674.

A pathologic process that has spread from its original site of growth to multiple distant anatomic sites. 